\title{
PENGARUH THEURAPETIC EXERCISE WALKING TERHADAP SIRKULASI DARAH PERIFER PADA PASIEN DIABETES MELLITUS TIPE 2 DI RUMAH SAKIT ROYAL PRIMA MEDAN TAHUN 2019
}

\author{
Melati Silvia Simanjuntak, Karmila Br.Kaban, Mhd Yuda Satria, Dian Souvenir Waruwu, \\ Bonay A.M Fandu \\ Fakultas Keperawatan dan KebidananUniversitas Prima Indonesia \\ Silvia.melaty15@gmail.com
}

\begin{abstract}
Abstrak
Diabetes Mellitus merupakan penyakit kronik, progresif yang dikarakteristikkan dengan ketidakmampuan tubuh untuk melakukan metabolisme karbohidrat, lemak, dan protein awal terjadinya hyperglikemia. Kadar glukosa darah yang tinggi pada pasien DM tipe 2 menyebabkan peningkatan reactive oxygen species (ROS) dan menurunnya NO yang berdampak pada rusaknya sel endotel pembuluh darah serta terganggunya elastisitas pembuluh darah sehingga plaque akan mudah menempel, yang memberikan dampak pada penurunan sirkulasi darah perifer terutama terjadi di kaki. Therapeutic Exercise Walking dapat berfungsi untuk melancarkan sirkulasi darah karena latihan ini menyebabkan pembuluh darah banyak yang terbuka dan meningkatkan kapasitas oksidatif otot. Tujuan penelitian ini untuk mengetahui pengaruh Therapeutic Exercise Walking Terhadap Sirkulasi Darah Perifer pada pasien DM tipe 2. Jenis penelitian ini menggunakan quasi experiment dengan desain pretest-postest group, jumlah sampel sebanyak 12 orang responden dengan menggunakan teknik purposive sampling. Hasil penelitian menunjukkan ada pengaruh antara Therapeutic Exercise Walking Terhadap Sirkulasi Darah Perifer pada pasien DM tipe 2 dengan nilai $p$-value $=0,003$ melalui uji wilcoxon rank test. Berdasarkan hasil penelitian yang dilakukan, diharapkan penderita DM tipe 2 dapat menjadikan Therapeutic Exercise Walking sebagai penatalaksanaan nonfarmakologi untuk melancarkan sirkulasi darah perifer agar tidak terjadi ulkus diabetik.
\end{abstract}

Kata Kunci : Therapeutic Exercise Walking, DM tipe 2, Sirkulasi darah perifer, Nilai ABI

\section{PENDAHULUAN}

Diabetes Mellitus (DM) atau sering disebut sebagai penyakit kencing manis merupakan suatu keadaan dimana tubuh tidak bisa menghasilkan hormon insulin sesuai kebutuhan, sehingga terjadi kelonjakan kadar gula dalam darah melebihi normal. Diabetes Mellitus tipe 2 dikarakteristikkan dengan hiperglikemia, resistensi insulin dan kerusakan relatif sekresi insulin (Soegondo, dkk, 2009).

Menurut Black \& Hawk (2009), Diabetes Mellitus merupakan penyakit kronik, progresif yang dikarakteristikkan dengan ketidakmampuan tubuh untuk melakukan metabolisme karbohidrat, lemak, dan protein awal terjadinya hyperglikemia (kadar gula yang tinggi dalam darah).

Menurut International Diabetes Federation (IDF), Diabetes Mellitus adalah salah satu masalah kesehatan yang serius pada masa sekarang. Setiap tahunnya, jumlah penderita DM terus bertambah dan semakin berdampak pada peningkatan masalah kesehatan apabila terjadi komplikasi pada penderitanya. IDF menemukan $85-95 \%$ kasus diabetes dari seluruh penderita di seluruh dunia adalah DM tipe 2. Selain itu, prevalensi orang dewasa yang mengalami gangguan toleransi glukosa berhubungan erat dengan DM tipe 2 (Bilous, 2014).

International Diabetes Federation (2014) telah melaporkan terdapat kematian sebesar 4,6 juta setiap tahunnya dan lebih dari 10 juta pasien mengalami kelumpuhan dan komplikasi seperti serangan jantung, stroke, gagal ginjal, kebutaan dan amputasi.Diabetes Mellitus tipe 2 merupakan penyakit kronis yang terjadi ketika pankreas tidak dapat menghasilkan hormon insulin yang cukup atau ketika tubuh tidak efektif menggunakan insulin yang dihasilkan (WHO, 2011).

Menurut data Riskesdas (2013), proporsi DM di Indonesia adalah $6,9 \%$. Prevalensi diabetes di Indonesia tahun 2013 adalah 2,1\%. Angka tersebut lebih tinggi dibanding dengan tahun $2007(1,1 \%)$. Sebanyak 31 provinsi yang ada di Indonesia $(93,9 \%)$ menunjukkan kenaikan prevalensi DM (Profil Kesehatan Indonesia, 2014). Hasil Riskesdas 2013 menunjukkan prevalensi tertinggi adalah provinsi Sulawesi Tengah (3,7\%), provinsi terendah adalah Bengkulu dan Kalimantan Barat (1\%). Provinsi Sumatera Utara memiliki prevalensi DM 
dengan komplikasi $(1,8 \%)$ dan proporsi penderita DM dengan komplikasi 2,3\%.

Penilaian gangguan sirkulasi darah perifer dapat dilakukan dengan nilai Ankle Brachial Index (ABI). Nilai ABI diperoleh dari pembagian tekanan sistolik kaki dibagi dengan tekanan sistolik brakhialis. Nilai ABI yang rendah pada pasien DM berhubungan dengan risiko adanya gangguan sirkulasi darah perifer yang lebih tinggi.Salah satu penatalaksanaan DM yang bisa dilakukan untuk meningkatkan sirkulasi darah adalah melakukan latihan jasmani. Latihan jasmani sangat penting pada pencegahan timbulnya diabetes tipe 2 seperti juga melakukan anjuran makan sehat. Kombinasi melakukan anjuran makan sehat dan latihan jasmani akan membantu pengendalian berat badan dan mencegah timbulnya diabetes. Peningkatan aktivitas fisik mengakibatkan berkurangnya faktor resiko sindrom metabolik dan mengurangi resiko penyakit jantung serta meningkatkan kebugaran jantung dan pembuluh darah.

Therapeutic Exercise Walking merupakan salah satu jenis latihan fisik aerobik yang ringan, aman dan dapat dilakukan kapan saja dan dimana saja. Therapeutic Exercise Walking dapat berfungsi untuk melancarkan sirkulasi darah karena latihan ini menyebabkan pembuluh darah banyak yang terbuka dn meningkatkan kapasitas oksidatif otot. Jalan kaki adalah salah satu cara terbaik yang paling dianjurkan untuk aktivitas fisik atau latihan jasmani sehari-hari. Sasaran jangka panjang yang banyak diinginkan orang dewasa adalah 10.000 langkah perhari setara dengan $8 \mathrm{~km}$ untuk seseorang yang panjang langkahnya rata-rata.

Berdasarkan hasil survei awal yang telah dilakukan peneliti pada tanggal 13 Maret 2019 menyatakan bahwa data tiga bulan terakhir pada tahun 2019 sebanyak 36 orang yang menderita Diabetes Mellitus Tipe 2. Berdasarkan hasil wawancara awal peneliti dengan 4 pasien Diabetes Mellitus Tipe 2, yang belum pernah mendapatkan edukasi maupun Theurapetic Exercise Walking, mereka mengatakan ingin melakukan Theurapetic Exercise Walking untuk mencegah terjadinya ulkus kaki. Kemudian dilaksanakan pemeriksaan Ankle Brachial Index untuk mengetahui sirkulasi darah perifer, pada 6 pasien DM tipe 2 dengan hasil rata-rata 0,8 yang artinya terjadi gangguan sedang pada peredaran darah kaki.

Berdasarkan data diatas maka, peneliti tertarik melakukan penelitian tentang "Pengaruh therapeutic exercise walking terhadap sirkulasi darah perifer pada pasien diabetes mellitus tipe 2 di rumah sakit royal prima medan tahun 2019"'.

\section{METODE PENELITIAN}

Jenis penelitian ini menggunakan quasi experiment yaitu jenis penelitian eksperimen yang tidak perlu memenuhi persyaratan seperti penelitian eksperimen sebenarnya yang dikatakan ilmiah mengikuti peraturanperaturan tertentu (Arikunto, 2014). Pada penelitian ini digunakan desain pretest-postest group dimana observasi atau pengukuran sirkulasi darah perifer dilakukan sebanyak dua kali yaitu sebelum dan sesudah pemberian theraupetic exercise walking. Populasi dalam penelitian ini adalah pasien yang menderita DM Tipe 2 di RSU Royal Prima Medan tahun 2019 Sebanyak 36 orang. Teknik pengambilan sampel dengan purposive sampling memiliki kriteria inklusi dan ekslusi (Nursalam, 2009). Jumlah sampel sebanyak 12 orang pasien penyakit Diabetes Milletus Tipe 2 di RS Royal Prima Medan tahun 2019. Metode pengumpulan data menggunakan media lembaran observasi untuk memperoleh data mengenai sirkulasi darah perifer yang sedang dialami oleh responden dimana penilaian gangguan sirkulasi darah perifer dapat dilakukan dengan nilai Ankle Brachial Index $(A B I)$..

\section{HASIL PENELITIAN}

\section{Karakteristik Penelitian}

Tabel 1

Karakteristik Responden Berdasarkan Lama Menderita, Jenis Kelamin dan Usia Pada Pasien Diabetes Mellitus Tipe 2 di Rumah Sakit Umum Royal Prima Medan Tahun 2019

\begin{tabular}{lcc}
\hline \multicolumn{1}{c}{ Variabel } & $\begin{array}{c}\text { Jumlah } \\
(\mathbf{n})\end{array}$ & $\begin{array}{c}\text { Persentase } \\
(\mathbf{\%})\end{array}$ \\
\hline Lama & & \\
Menderita & & \\
(Tahun) & & \\
$\quad<5$ & 9 & 75 \\
$\quad>5$ & 3 & 25 \\
$\quad$ Total & 12 & 100 \\
Jenis Kelamin & & \\
$\quad$ Laki-laki & 5 & 41,7 \\
$\quad$ Perempuan & 7 & 58,3 \\
$\quad$ Total & 12 & 100 \\
Usia & & \\
(Tahun) & & \\
$\quad<56$ & 10 & 83,3 \\
$\quad>56$ & 2 & 16,7 \\
$\quad$ Total & 12 & 100 \\
\hline
\end{tabular}

Berdasarkan Tabel 1 dapat dilihat bahwa karakteristik lama menderita, mayoritas lama menderita DM $<5$ tahun yaitu sebanyak 9 responden (75\%) sedangkan $>5$ tahun yaitu sebanyak 3 responden $(25 \%)$. Karakteristik jenis kelamin menderita DM mayoritas adalah perempuan yaitu sebanyak 7 responden $(58,3 \%)$ sedangkan laki-laki yaitu sebanyak 5 responden $(41,7 \%)$. Karakteristik usia mayoritas yaitu usia $<56$ tahun yaitu sebanyak 10 responden $(83,3 \%)$ sedangkan usia $>56$ tahun yaitu sebanyak 2 responden $(16,7 \%)$.

\section{AnalisaUnivariat}

Tabel 2

Distribusi Frekuensi Nilai ABI (Sirkulasi Darah Perifer) Sebelum Dilakukan Therapeutic Exercise Walking Pada Pasien Diabetes Mellitus Tipe 2 di 


\section{Rumah Sakit Umum Royal Prima Medan Tahun} 2019

\begin{tabular}{clcc}
\hline No & $\begin{array}{c}\text { Kategori Nilai } \\
\text { ABI(Sirkulasi } \\
\text { Darah) Post Test }\end{array}$ & $\begin{array}{c}\text { Jumlah } \\
\text { (n) }\end{array}$ & $\begin{array}{c}\text { Persentase } \\
(\mathbf{\%})\end{array}$ \\
\hline 1 & Normal & 2 & 16,6 \\
2 & Obstruksi Ringan & 5 & 41,7 \\
3 & Obstruksi Sedang & 5 & 41,7 \\
4 & Obstruksi Berat & - & - \\
& Total & $\mathbf{1 2}$ & $\mathbf{1 0 0}$ \\
\hline
\end{tabular}

Berdasarkan hasil tabel 6 dapat dilihat bahwa nilai $A B I$ (sirkulasi darah perifer) pasien diabetes mellitus tipe 2 sebelum dilakukan therapeutic exercise walking (pretest) dari 12 orang responden memiliki sirkulasi darah perifer (nilai $A B I$ ) dengan kategori normal sebanyak 2 responden $(16,6 \%)$, sirkulasi darah perifer (nilai $A B I$ ) dengan kategori obstruksi ringan sebanyak 5 responden (41,7\%), sirkulasi darah perifer (nilai $A B I$ ) dengan kategori obstruksi sedang sebanyak 5 responden $(41,7 \%)$ dan sirkulasi darah perifer (nilai $A B I$ ) dengan kategori obstruksi berat tidak ada responden.

Tabel 3

Distribusi Frekuensi Nilai $A B I$ (Sirkulasi Darah Perifer) Sesudah Dilakukan Therapeutic Exercise Walking Pada Pasien Diabetes Mellitus Tipe 2 di Rumah Sakit Umum Royal Prima Medan Tahun 2019.

\begin{tabular}{|c|c|c|c|}
\hline No & $\begin{array}{c}\text { Kategori Nilai } \\
\text { ABI (Sirkulasi } \\
\text { Darah) Post } \\
\text { Test }\end{array}$ & $\begin{array}{c}\text { Jumlah } \\
\text { (n) }\end{array}$ & $\begin{array}{c}\text { Persentase } \\
(\%)\end{array}$ \\
\hline 1 & Normal & 9 & 75 \\
\hline 2 & $\begin{array}{l}\text { Obstruksi } \\
\text { Ringan }\end{array}$ & 2 & 16,7 \\
\hline 3 & $\begin{array}{l}\text { Obstruksi } \\
\text { Sedang }\end{array}$ & 1 & 8,3 \\
\hline 4 & $\begin{array}{l}\text { Obstruksi Berat } \\
\text { Total }\end{array}$ & - & $\begin{array}{c}- \\
100\end{array}$ \\
\hline
\end{tabular}

Berdasarkan hasil table 7 dapat dilihat bahwa nilai $A B I$ (sirkulasi darah perifer) pasien diabetes mellitus tipe 2 setelah dilakukan therapeutic exercise walking (post test) dari 12 orang responden memiliki sirkulasi darah perifer (nilai $A B I$ ) dengan kategori normal sebanyak 9 responden $(75 \%)$, sirkulasi darah perifer (nilai $A B I$ ) dengan kategori obstruksi ringan sebanyak 2 responden $(16,7)$, sirkulasi darah perifer (nilai $A B I$ ) dengan kategori obstruksi sedang sebanyak 1 responden $(8,3 \%)$ dan sirkulasi darah perifer (nilai $A B I$ ) dengan kategori obstruksi berat tidak ada responden.

\section{Analisa Bivariat}

Analisa bivariat dilakukan untuk melihat adanya pengaruh therapeutic exercise walking terhadap sirkulasi darah perifer pada pasien diabetes mellitus tipe 2 .

Tabel 4

Pengaruh Therapeutic Exercise Walking Terhadap Sirkulasi Darah Perifer Pada Pasien Diabetes Mellitus Tipe 2 di Rumah Sakit Umum Royal Prima Medan Tahun 2019.

\begin{tabular}{cccccc}
\hline $\begin{array}{c}\text { Sirkulasi } \\
\text { Darah } \\
\text { Perifer }\end{array}$ & $N$ & Mean & $S \boldsymbol{D}$ & $\boldsymbol{Z}$ & $\begin{array}{c}\boldsymbol{P} \text { - } \\
\text { Value }\end{array}$ \\
\hline Pre Test & 12 & 0,87 & 0,15178 & - & \\
Post Test & 12 & 1,04 & 0,10250 & $2,983^{\mathrm{b}}$ & 0,003 \\
\hline
\end{tabular}

Berdasarkan hasil analisis tabel 8 menunjukkan bahwa dari 12 responden penderita DM tipe 2 diperoleh hasil perhitungan wilcoxon signed rank test dengan nilai $\mathrm{z}$ sebesar $-2,983^{\mathrm{b}}$ dan $p$-value $0,003<0,05$ artinya ada pengaruh yang signifikan terhadap sirkulasi darah perifer (nilai $\mathrm{ABI}$ ) pada pasien DM tipe 2 sebelum dan sesudah intervensi.

\section{PEMBAHASAN}

Sirkulasi Darah Perifer Dapat Dilihat dari Nilai ABI Sebelum Dilakukan Therapeutic Exercise Walking Pada Pasien Diabetes Mellitus Tipe 2

Hasil penelitian ini juga berkaitan dengan hasil penelitian Atik, dkk, 2014 tentang pengaruh senam kaki terhadap sirkulasi darah perifer dilihat dari nilai $A B I$ pada pasien DM mengatakan saat pretest 17 responden mengalami obstruksi ringan $(56,7 \%)$ dan 13 responden mengalami obstruksi sedang $(43,3 \%)$.

Maka dari hasil penelitian tersebut dapat disimpulkan bahwa faktor penyebab responden berada dalam kategori nomal karena responden memiliki riwayat menderita DM $<5$ tahun, usia responden $<56$ tahun dan responden yang berada dalam kategori obstruksi ringan dan sedang memiliki riwayat lama menderita DM $>$ 5tahun, usia >56 tahun dan mereka belum pernah mendapatkan edukasi tentang therapeutic exercise walking atau pentingnya latihan fisik seperti jalan kaki selama 30 menit, maka dari itu setelah mendapatkan edukasi dari peneliti, responden sangat tertarik untuk melakukan intervensi ini, karna responden tidak ingin mengalami resiko tinggi terhadap ulkus diabetik pada bagian kaki. Oleh karena itu peneliti berpendapat bahwa sirkulasi darah perifer yang terhambat dibagian kaki akan menimbulkan resiko ulkus diabetik, dengan diberikannya therapeutic exercise walking dapat memperlancar sirkulasi darah perifer.

Sirkulasi Darah Perifer Dapat Dilihat dari Nilai $A B I$ Sesudah Dilakukan Therapeutic Exercise Walking Pada Pasien Diabetes Mellitus Tipe 2 
Berdasarkan hasil penelitian pada tabel 3.1.3 diketahui bahwa dari 12 responden setelah dilakukan therapeutic exercise walking, diketahui bahwa mayoritas responden dalam kategori normal adalah sebanyak 9 orang (75\%), kategori obstruksi ringan adalah sebanyak 2 orang $(16,66)$, kategori obstruksi sedang sebanyak 1 orang $(8,33 \%)$.

Dari hasil penelitian diatas peneliti dapat menyimpulkan bahwa setelah dilakukannya therapeutic exercise walking dengan latihan fisik aerobik yang ringan seperti jalan kaki yang berlangsung selama 30 menit sangat berpengaruh terhadap peningkatan sirkulasi darah perifer pada penderita DM tipe 2 yang dilihat dengan nilai $A B I$, oleh karena itu peneliti berpendapat bahwa sirkulasi darah perifer yang terhambat dibagian kaki akan menimbulkan resiko ulkus diabetik, dengan diberikannya therapeutic exercise walking dapat memperlancar sirkulasi darah perifer dan sangat baik dilakukan pada pagi dan sore hari.

Hasil penelitian ini sejalan dengan hasil penelitian Made, dkk 2016 tentang pemeriksaan ABI post exercise pada pasien DM dengan $P A D$ dengan sampel 17 sampel dengan menggunakan tes uji $\mathrm{t}$ dependen dan menunjukkan perbedaan yang signifikan nilai ABI sebelum dan sesudah latihan dengan nilai kaki kanan 0,004 dan kaki kiri 0,000.

\section{Pengaruh Therapeutic Exercise Walking Terhadap Sirkulasi Darah Perifer Pada Pasien Diabetes Mellitus Tipe 2 dari Nilai $A B I$}

Berdasakan hasil penelitian diatas peneliti dapat menyimpulkan bahwa sebelum dilakukannya therapeutic exercise walking (pre test) mayoritas pasien dalam kategori obstruksi ringan dan obstruksi sedang dan setelah dilakukannya therapeutic exercise walking (post test) mayoritas responden dalam kategori normal artinya ada pengaruh yang signifikan terhadap peningkatan sirkulasi darah perifer. Data diatas diperoleh dari hasil pembagian tekanan sistolik kaki dibagi dengan tekanan sistolik brakhialis responden kemudian hasil pembagiannya dinilai dengan aspek pengukuran Ankle Brachial Index $(A B I)$.

Hasil penelitian ini sejalan dengan hasil penelitian Yitno dan Asep, 2017 tentang pengaruh jalan kaki ringan 30 menit terhadap penurunan kadar gula darah pada lansia penderita diabetes mellitus tipe 2 dengan sampel sebanyak 24 responden, sebelum dilakukan perlakuan jalan kaki terdapat 20 responden (83\%) mempunyai kadar gula darah acak dalam kategori diabetik dan sesudah dilakukan perlakuan jalan kaki terdapat 14 responden $(58,3 \%)$ mempunyai kadar gula darah acak dalam kategori diabetik artinya ada pengaruh latihan jalan kaki ringan 30 menit terhadap penurunan kadar gula darah pada lansia DM tipe 2 yang ditunjukkan dengan nilai $p=0,000$ dan $\alpha=0,05$.

Hasil penelitian ini sejalan dengan hasil penelitian Weny, dkk, 2018 tentang pengaruh pemberian latihan fisik jalan kaki terhadap penurunan kadar gula darah pada pasien DM tipe 2 dengan sampel sebanyak 11 responden menunjukkan adanya pengaruh penurunan kadar gula darah dengan melakukan latihan fisik jalan kaki pada minggu pertama terjadi penurunan $9.16 \mathrm{mg} / \mathrm{dl}$, minggu kedua $9.51 \mathrm{mg} / \mathrm{dl}$ dan minggu ketiga $12.94 \mathrm{mg} / \mathrm{dl}$ dengan $p$-value $0.000(\mathrm{p}-0.05)$. Dari hasil penelitian ini didapatkan bahwa adanya pengaruh latihan fisik jalan kaki yang dilakukan terhadappenurunan kadar gula darah pada penderita DM Tipe II.

Hasil penelitian sesuai dengan hasil penelitian Dewa, dkk, 2013 tentang latihan aerobik dengan jalan kaki pada pasien DM tipe 2 dengan sampel sebanyak 30responden, hasil penelitian menunjukkan rata-rata $C R T$ ekstremitas bawah sebelum perlakuan pada kelompok perlakuan adalah 2,8 detik dan kelompok kontrol adalah 2,72 detik, setelah perlakuan diperoleh rata-rata $C R T$ ekstremitas bawah adalah 1, 48 detik pada kelompok perlakuan dan 2,77 detik pada kelompok kontrol dengan $p=0,000<\alpha(0,05)$ artinya ada pengaruh yang signifikan pemberian latihan aerobik jalan kaki terhadap $C R T$ ekstremitas bawah pada penderita DM tipe 2 .

Hasil penelitian ini sesuai dengan hasil penelitian Anisa, 2016 tentang pengaruh jalan kaki dan senam kaki terhadap kadar glukosa darah penderita DM tipe 2 dengan sampel sebanyak 20 responden, berdasarkan hasil uji wilcoxon pada efek akut (sebelum dan setelah latihan) jalan kaki diperoleh nilai $p=0,005$ dan senam kaki dengan nilai $p=0,005$. Sedangkan efek kronis (sebelum dan setelah 4 minggu latihan) jalan kaki diperoleh nilai $p=0,092$ dan senam kaki dengan nilai $p$ $=0,24$. Dari hasil uji mann whitney diperoleh nilai p efek akut $=1,000$ dan nilai $p$ efekkronis $=0,85$ artinya Terdapat pengaruh akut yang signifikan antara sebelum dan setelah perlakuan jalan kaki dan senam kaki, tidak terdapat pengaruh kronis antara sebelum dan setelah 4 minggu perlakuan jalan kaki dan senam kaki, dan tidak terdapat perbedaan pengaruh akut dan kronis yang signifikan antara jalan kaki dan senam kaki terhadap kadar glukosa darah penderita diabetes mellitus tipe 2 .

Hasil Penelitian ini menggambarkan bahwa dengan latihan jalan kaki selama 30 menit yang dilakukan secara rutin ternyata mampu meningkatkan sirkulasi darah perifer yang dapat dilihat dari nilai $A B I$. Menurut asumsi peneliti intervensi ini akan lebih efektif apabila terapi jalan kaki ini dilakukan secara teratur oleh penderita DM tipe 2. Hasil analisa statistik setelah dilakukan therapeutic exercise walking terhadap sirkulasi darah perifer dengan aspek pengukuran yang dikategorikan dengan nilai ABI maka diperoleh nilai rata-rata 0,87 sebelum dilakukan therapeutic exercise walking (pre test) ada peningkatan setelah dilakukan therapeutic exercise walking dengan nilai rata-rata 1,04 . sesuai dengan hasil perhitungan uji wilcoxon signed rank test yang menunjukkan nilai signifikan $p$-value $=0,003$ yang artinya ada pengaruh yang signifikan terhadap sirkulasi darah perifer setelah dilakukannya therapeutic exercise walking pada pasien DM tipe 2 di RSU Royal Prima Medan Tahun 2019.

\section{DAFTAR PUSTAKA}

American Diabetic Association. 2010. Classification of diabetes. Jurnal Elektronik diakses http//care.diabetesjournals.org/content/35/supple ment_1 /S64.full.pdf+htm 
American Diabetes Association. Standards of medical care in diabetes. 2013. Diakses dari care.diabetesjournals.org/content/36.supplement_ 1/S11. full. pdf

Amir.The effect of 4-weeks aerobic training according with the usage of anethum gravelens on blood sugar and lipoproteins profile of diabetic women. Diakses dari: www.scholarsresearchlibrary.com

Hans T. 2007. Segala Sesuatu Yang Harus anda Ketahui Tentang Diabetes: Panduan Lengkap Mengenal Dan Mengatasi Diabetes Dengan Cepat Dan Mudah. Jakarta: PT. Gramedia Pustaka.

Indonesia. Perkumpulan Endokrin Indonesia (Perkeni). 2011. Konsessus Pengelolaan dan Pencegahan Diabetes Mellitus Tipe 2 di Indonesia. 2011. Diakses dari http://www.perkemi.org

Indonesia. Riset Kesehatan Dasar (Riskesdas). RisetKesehatanDasar 2013. Jakarta: Badan Penelitian dan Pengembangan Kesehatan Kementrian Kesehatan RI; 2013.

International Diabetes Federation (IDF). Diabetes Atlas. Edisi 6. 2012

Internasional Diabetes Federation. 2013. Diabetes Atlas: Impact On The Individual. Diakses dari http://da3.diabetesatlas.org/index 68fc.htmt.
Jeffrey JS \& Chaikof EL. Depatogenesis of Diabetic Atherosklerosis. 2012. Diakses dari http://.springer.com/cda/content/document/cda_d ownlo addocument/9781627031578c1.pdf?SGWID=0

Kuntaraf K. Olahraga Sumber Kesehatan. Jakarta: Indonesia Pubhlising House; 1996.

Maria S. Hubungan antara penyakit arteri perifer dengan faktor resiko cardiovaskular pada pasien DM tipe 2

Marlene SG, dkk. Angkle Brachial Index For Assesment Of Peripheral Arterial Disease.

Notoatmojo, 2012. MetedologiPenelitianKesehatan. Jakarta :RinekaCipta, 2012.

PERKENI (2015). Konsesus Pengelolaan dan Pencegahan Diabetes Mellitus tipe 2 di Indonesia. Jakarta . PB PERKENI

Soegondo S., 2009. Buku Ajar Penyakit Dalam: Insulin :Farmakoterapi Pada Pengendalian Glikemia Diabetes Mellitus Tipe 2, Jilid III, Edisi 4. Jakarta: FK UI.

Sylvia AP \& Lorraine MW. 2006. Patofisiologi: Konsep Klinis Prose-Proses Penyakit: Edisi 6, Vol 2, Alih Bahasa, Brahm U. Pendit. Jakarta: EGC.

Yunir M, dkk. 2015. Upaya Pencegahan Diabetes Tipe 2: Edisi pertama. Jakarta: Anggota IKAPI 